HIV incidence in pregnancy, Fort Portal- Study Questionnaire

Hospital registration Number

Date of visit

Study ID

Staff name

\title{
Client Information
}

1. Client Type: $\quad$ ANC client $\square \quad$ If ANC client, gestational week:

ANC visit no:

OR

Delivery client $\square$

If delivery client, date of delivery:

2. Age (years):

3.Gravida:

4.Para:

5. Date last HIV test BEFORE repeat test:

/Gest. week: Confirm test was negative: $\square$

6. Marital status: Married/Cohabiting couple $\square \quad$ Not cohabiting couple $\square \quad$ Single $\square \quad$ Widowed $\square \quad$ Divorced $\square$ 7. Completed education: $\quad$ None $\square \quad$ Primary $\square \quad$ Secondary $\square \quad$ Tertiary $\square$

8. Occupation: Housewife $\square$ Farmer $\square$ Trader $\square$ Civil Service $\square$ Other $\square$ :

9. Religion: 10. Residence: Fort Portal $\square$ Other $\square$, specify:

11. Travel distance Hospital minutes: 12.Travel cost (one-way, UGX):

13. No. of people living in household: 14. No. children $<15$ in household:

15. Is the following present in the household:

Electricity
Cupboard
TV
Cattle
Mosquito- net

\section{Yes $\square$}

No $\square$

Pipe borne water

Yes $\square$

No $\square$

Radio

Yes $\square$

No $\square$

Fridge

Yes $\square$

No $\square$

Yes $\square$

No $\square$

Mosquito- net

Yes $\square$

Yes $\square$

No $\square$

No $\square$

Yes $\square$

No $\square$

Motor-bike, Car

-

Partner Information (applies for husband/partner, or father of this baby)

16. Age (years):

18. Completed education: $\quad$ None $\square$
17. Partnership duration in years/months:

Primary $\square \quad$ Secondary $\square \quad$ Tertiary $\square$
Farmer $\square \quad$ Fisherfolk $\square \quad$ Trader $\square \quad$ Civil Service $\square \quad$ Trucker $\square$

Armed Forces $\square$ Other $\square$, specify:

20. Religion:

21. Residence: Fort Portal $\square$ Other $\square$, specify:

22. HIV status of partner known to woman $\square \quad$ unknown to woman $\square \quad$ If known: positive $\square$

23. When was partner tested for HIV the last time?

24. Was HIV testing or status ever discussed in between the couple?

Yes $\square$

25. Has your partner ever accompanied you to ANC during this pregnancy?

Yes $\square$

No

If yes, was joint HIV partner testing performed in ANC during this pregnancy?

Yes $\square$

No $\square$

26. Was HIV testing ever done jointly? Yes $\square$, when?

27. Is your partner circumcised?

Yes $\square, \quad$ since: 


\section{Behavioral information, client}

28. Do you think you might be at risk of getting HIV? High risk $\square \quad$ Some risk $\square$ Very low risk $\square \quad$ Not at risk $\square$

29. Have you been sexually active in this pregnancy? Yes $\square$ : average no. sexual acts per month

No $\square$ If yes, how often did you use a condom? $\quad$ Always $\square \quad$ Sometimes $\square \quad$ Rarely $\square \quad$ Never If not always, please state reasons for not using condoms:

30. Do you know how to use condoms? Yes $\square$ No $\square$

31. Do you know where to get condoms? Yes $\square$ No $\square$

32. How many sexual partners did you have: in the past year? During this pregnancy?

33. In the past year, have you engaged in any of the following:

Intravenous drug use $\square \quad$ Commercial sex work $\square$

Unprotected sex with someone not known well $\square$

Trading sex for food or other goods or benefits $\square \quad$ Alcohol abuse $\square$ Sex under influence of alcohol/drugs $\square$ Sex with someone who was under influence of alcohol/drugs $\square$ Sex involving anal intercourse $\square$

If yes for any of these, please specify when/how often:

34. Are you aware of any sexually transmitted disease (STD) you have had during this pregnancy?

No $\square \quad$ Yes $\square$, please specify symptoms or diagnosis:

If yes, have you received medical care for the disease? Yes $\square \quad$ No $\square$

35. Do you suffer from any mental health condition? No $\square$ Yes $\square$, specify:

Behavioral information, partner (applies for husband/partner, or father of this baby)

36. Do you ever discuss condom use with your partner? Yes $\square$ No $\square$, why not?

37. Does your partner agree to use a condom when you ask him to? Always $\square \quad$ Mostly $\square \quad$ Rarely $\square$ Never $\square$

38. Do you generally consider your partner as being faithful?

Yes $\square \quad$ No $\square$ Don't know $\square$

39. Are you aware of other sexual relationships your partner may have? $\quad$ Yes $\square \quad$ No $\square$ Don't know $\square$

40. Does your partner spend much time abroad or away from home? $\quad$ Yes $\square \quad$ No $\square$

If yes, please specify reason and frequency:

41. To your knowledge, does your partner ever abuse alcohol $\square \quad$ use intravenous drugs $\square \quad$ visit sex workers $\square$ If yes, please estimate frequency of events

42. Have you ever experienced any physical violence by your partner? $\quad$ Yes $\square \quad$ No $\square$ If yes, please specify frequency and event:

43. Has your partner ever repressed/threatened you emotionally $\square \quad$ financially (e.g. depriving of money) $\square$ If yes, specify:

44. Are you financially dependent on your partner? Completely $\square$ For the most part $\square \quad$ For some part $\square \quad$ Not at all $\square$

\section{Result of client's HIV repeat test}

Repeat test performed during this session today $\square$

Result was positive

Result was negative $\square$

OR (only if a repeat HIV test was performed already, at a time less than 3 months ago)

Result transferred from hospital records $\square$ Date of repeat test /Gest. week

Test result of transferred hospital records:

Result was positive Result was negative $\square$ 